\section{Ebola virus control needs local buy-in}

International guidelines describe effective measures for the prevention and control of the Ebola virus. But we need more practical information on how to implement these measures, including potential therapies and a safe vaccine, in non-Western settings (Nature 513, 13-14; 2014).

Culturally tailored procedures must be detailed in international public-health protocols, drawing on the expertise of medical anthropologists. Such measures will also help to overcome mistrust of authorities and field workers among affected populations.

The current Ebola outbreak will not be controlled without the local population's understanding and cooperation.

Gilles Guerrier Hôtel-Dieu and Cochin Hospitals, Paris Descartes University, France.

Eric D’Ortenzio Solthis, France; and Bichat Hospital, Paris, France. guerriergilles@gmail.com

\section{Climate models: sunk by humans?}

Paul Palmer and Matthew Smith's argument that human adaptation to climate change should be incorporated into climate-projection models is entirely reasonable (Nature 512, 365-366; 2014). However, I suspect that doing so could render such models essentially useless.

Climate models are created with the intention of providing predictions that are more reliable, and as such must always wrestle with the bias-variance dilemma. Introducing human responses to climate change will make this issue much more challenging than it already is and perhaps hopelessly so.

To put it bluntly, one does not need to be an expert in modelling non-linear systems to recognize that the best answer to the question 'How can we get more precise predictions?' is never 'Add lots more variables'. Robert A. J. Matthews Didcot, UK.

rajm@physics.org

\section{Climate models: use archaeology record}

Archaeologists and historians have long investigated societal responses to climate change (see P. Palmer and M. Smith Nature 512, 365-366; 2014). These records are an underused resource in current climateadaptation research, but offer scope for highly integrative meta-analyses that would be useful to climate scientists, science advisers and policymakers, and could provide important information for local outreach efforts.

Risk-reduction researchers have pointed out that responses to climate change are a mix of contemporary industrial (technological) measures and pre-industrial (social and community-based) ones. However, the use of palaeoenvironmental data by the Intergovernmental Panel on Climate Change as a basis for drawing up future climatechange scenarios is not matched by an equally sophisticated use of 'palaeosocietal' data for investigating human impacts and adaptive pathways.

Archaeological and historical data could provide a solid evidence base for effective adaptations to climate change. Expanding the chronological scope of climate-adaptation research into deep time would vastly enlarge the database of available case studies without getting into the tricky issues of data access and legal sensitivity. In effect, this approach draws on natural experiments in history to learn from the past (see R. Van der Noort Climate Change Archaeology Oxford Univ. Press; 2013).

Felix Riede Aarhus University,
Højbjerg, Denmark.

f.riede@cas.au.dk

\section{Monitor Brazil's fish sampling closely}

Brazil's aquaculture and fisheries secretary decreed last month that 2,000 different species of ornamental fish can be legally removed from the Brazilian Amazon. The fish will be farmed to supply the aquarium trade. This raises concerns about over-exploitation and threats to biodiversity, particularly given the poor record of inspection and reinforcement by the country's environmental agencies (see A. L. B. Magalhães and J. R. S. Vitule Science 341, 457; 2013).

The new ruling could stimulate indiscriminate extraction, biopiracy, fish trafficking and the escape of farmed species into ecoregions of the country where they are not native. Close monitoring must be a priority.

We should be educating people about how to conserve Brazil's exuberant aquatic diversity, not encouraging its plunder.

Jean R. S. Vitule Federal University of Paraná, Curitiba, Brazil. Flávia D. F. Sampaio Federal Institute of Paraná, Curitiba, Brazil. André L. B. Magalhães Pontifical Catholic University of Minas Gerais, Belo Horizonte, Brazil. andrebiomagalhaes@gmail.com

\section{Shale gas is a fraught solution to emissions}

Qiang Wang suggests that shale gas might be used as a bridging fuel to cap China's carbon emissions (Nature 512, $115 ; 2014)$. Extraction and development problems could make this difficult.

The greenhouse-gas footprint of shale gas is much bigger than that of coal. Shale gas emits less carbon dioxide than coal or oil when burnt, but the methane produced during the extraction process has a global-warming potential 70 times that of $\mathrm{CO}_{2}$ (see R. W. Howarth et al. Nature 477, 271-275; 2011).

Following the US shale-gas boom, China devised a plan to extract its own gas resources. This proved difficult and expensive owing to limited water availability and because the gas is located at depth under large amounts of subsurface clay.

Furthermore, extraction might compromise the country's already stressed aquatic environments ( $\mathrm{H}$. Yang et al. Nature 499, 154; 2013) and increase seismic activity important factors in densely populated areas such as southwest China.

As a result, Chinese shale-gas production in 2013 was only around $3 \%$ of that planned for 2015. Last month, this forced the country to halve its production target for 2020 (see go.nature. $\mathrm{com} / \mathrm{h} 5 \mathrm{mtza}$; in Chinese).

In our view, China would be better off investing more in renewable energy and improving energy efficiency.

Hong Yang University of Oslo, Norway.

Julian R. Thompson University College London, UK.

hongyanghy@gmail.com

\section{Aristotle's suspect statistical skills}

In his review of Armand Marie Leroi's book The Lagoon (Nature 512, 250-251; 2014), Roberto Lo Presti rightly praises Aristotle's observational skills. But the philosopher may not have been as adroit in numeracy as he was in biology.

Aristotle famously declared that "males have more teeth than females in the case of men, sheep, goats, and swine" (see his History of Animals, Book 2, Part 3). This was an obvious sampling mistake, which bears out the importance today of a strong statistical foundation for biological curricula.

Taner Z. Sen Ames, Iowa, USA. tanerzsen@gmail.com 